THE CORD KEEPERS 
A book in the series

Latin America Otherwise: Languages, Empires, Nations Series editors:

Walter D. Mignolo, Duke University Irene Silverblatt, Duke University Sonia Saldívar-Hull, University of California at Los Angeles 


\section{THE CORD KEEPERS}

Khipus and Cultural Life in a Peruvian Village

Frank Salomon

DUKE UNIVERSITY PRESS Durham and London 2004 
(C) 2004 Duke University Press

All rights reserved

Printed in the United States of America on acid-free paper @ Typeset in Minion by Tseng Information Systems, Inc.

Library of Congress Cataloging-in-Publication Data appear on the last printed page of this book. 
TO JOHN V. MURRA

WHO TAUGHT:

"No digan 'perdido.' Digan 'aún no encontrado."” "Don't say 'lost.' Say 'not yet found." 
